\title{
Skin Whitening Effects of Angelica koreana and Cnidium monnieri Extracts
}

\author{
Wan Goo Cho*, Cheong Tack Kim** \\ Dept. of Basic Medical Science, Jeonju University ${ }^{*}$ \\ $\mathbf{R} \& \mathbf{S}^{* * *}$ \\ 강활과 벌사상자 추출물의 피부 미백효과 \\ 조완구 ${ }^{*}$, 김청택 ${ }^{* *}$ \\ 전주대학교 기초의과학과 ${ }^{*}$, 주)알앤애스 ${ }^{*}$
}

\begin{abstract}
The objective of this study is to estimate the inhibition of skin melanin formation by extract of Angelica koreana and Cnidium monnieri and the possibility of functional cosmetic materials through anti-irritation and stability test. The extract used in this experiment is White- $\mathrm{AK}{ }^{\mathrm{TM}}$ and the INCI name is Osthole. The main component of White- $\mathrm{AK}^{\mathrm{TM}}$ was identified as coumarin and EC50 value was $2.7 \mathrm{ppm}$ by mouse melanoma B 16 cell test. White- $\mathrm{AK}^{\mathrm{TM}}$ showed inhibitory effects 100 times lower concentration than arbutin. The main mechanism for skin whitening effect thought to be inhibition of tyrosinase-related gene expression. The basic essence formulation of White- $\mathrm{AK}^{\mathrm{TM}} 5 \%$ solution applied to the skin showed the effect of relieving skin irritation. White- $\mathrm{AK}^{\mathrm{TM}}$ in an opaque container, under UV conditions for 4 weeks, and showed close to $100 \%$ recovery and $97 \%$ recovery under $50 \mathrm{oC}$ for 4 weeks. Therefore, it is thought that White- $\mathrm{AK}^{\mathrm{TM}}$ which helps skin whitening, relieving skin irritation and stable in UV condition is able to be used as the functional component in the cosmetic formulation.
\end{abstract}

Key Words : Angelica koreana, Cnidium monnieri, tyrosinase, skin whitening, cosmetics

요 약 본 연구의 목적은 강활과 벌사상자 추출물에 의한 피부 멜라닌 형성 저해와 안정성과 자극성 시험을 통하여 기능성 화장품의 사용 물질 가능성을 평가하고자 하였다. 본 실험에 사용된 추출물은 White-AK ${ }^{\mathrm{TM}}$ 이고 INCI 명칭은 Osthole이다. White- $\mathrm{AK}^{\mathrm{mm}}$ 의 주성분은 쿠마린이고 EC50 값은 마우스 멜라노마 B16 세포 시험에서 $2.7 \mathrm{ppm}$ 이였다. White- $\mathrm{AK}^{\mathrm{TM}}$ 는 알부틴보다 100 배 낮은 농도에서 저해 효과를 보였다. 미백 효과의 주 기작은 티로시나제-관련 유전자 발현을 저해하는 것으로 생각되었다. White- $\mathrm{AK}^{\mathrm{TM}} 5 \%$ 용액을 함유한 기본적인 에센스 처방을 피부에 적용 시 피부자 극을 경감시켰다. White- $\mathrm{AK}^{\mathrm{TM}}$ 은 불투명한 용기에서 4 주간 자외선 하에서 $100 \%$ 의 회수율을 보였고 $50 \mathrm{oC}$ 에서 4 주간 $97 \%$ 의 회수율을 보였다. 따라서 피부 미백효과와 자극성 경감효과가 있고 자외선 조건하에서 안정한 White- $\mathrm{AK}^{\mathrm{TM}}$ 은 화장품 처방에서 기능성 원료로 사용될 수 있을 것으로 사료된다.

주제어 : 강활, 벌사상자, 티로시나제, 피부 미백, 화장품

\footnotetext{
* 본 논문은 2013년 글로벌코스메틱사업단의 학술연구비에 의하여 지원되었음

Received 18 February 2014, Revised 5 March $2014 \quad$ (C) The Society of Digital Policy \& Management. All rights Accepted 20 April 2014 reserved. This is an open-access article distributed under the Corresponding Author: Wan Goo Cho(Dept. of Basic Medical terms of the Creative Commons Attribution Non-Commercial Science, Jeonju University)

Email: wgcho@jj.ac.kr License (http://creativecommons.org/licenses/by-nc/3.0), which permits unrestricted non-commercial use, distribution, and

ISSN: $1738-1916$ reproduction in any medium, provided the original work is properly cited.
} 


\section{Introduction}

In recent years, the number of Asian women aspiring for a white skin complexion has increased dramatically. This is due partly to the discovery of many effective skin whitening agents, particularly those derived from natural sources such as arbutin, kojic acid and licorice extract. Implementation of a wide range of consumer desire for skin color is possible due to the development of computer graphic and algorithm [1][2].

Promotion of these substances by the cosmetic industry in various media has played a critical role in the widespread popularity of skin whitening products among women, especially in the Fareast and Southeast Asia. Also, it is traditional perception of the women in this region that a lighter skin provides them the appearance of grace, nobility and youthfulness, as evidenced in many Asian poems and songs, which often describe the beauty of a lady in association with the fairness of her skin.

The skin color is mainly determined by the content of an epidermal pigment called melanin. Its major function is to provide protection against ultraviolet (UV) radiation. However, excessive melanin production is not desirable in many people since it may cause a darker or uneven skin color. The initial process of melanin production (melanogenesis) is controlled by tyrosinase, which is an enzyme catalyzing the hydroxylation of tyrosine, the precursor of melanin, into dihydroxyphenylalanine(DOPA) and other intermediates. Thus, inhibition of tyrosinase activity or its production can prevent melanogenesis[3]. Several plant extracts were found to exhibit strong anti-tyrosinase activity in vitro such as those from Areca catechu L.[4], Artocarpus incisus[5], Broussonetia spp. (paper mulberry root bark extract) [6], Glycyrrhiza glabra (licorice extract) [7], Prunus spp. [8], and Rheum officinale [9]. Many of these extracts have been tested in vivo and commercially developed as skin whitening agents in cosmetic preparations such as kojic acid, licolice extract and Morus alba extract [10]. However, they are quite expensive and some of the users may develop skin hypersensitivity upon application especially when using high concentrations.

Artocarpus lakoocha Roxb is a tropical tree about 20-30 meters high commonly found throughout south and southeast asia. The main constituent in the heartwood extract is $2,4,3^{\prime}, 5^{\prime}$-tetrahydroxystilbene or oxyresveratrol [11].

Recently, Sritularak et al. [12] have screened a large number of plants for their in vitro antityrosinase activity and found that the heartwood extract of A. lakoocha exhibited the highest activity. Purification of the extract yielded two active components, namely, oxyresveratrol and resveratrol. The main objective of this study was to evaluate the whitening effect of extracts of Angelica koreana, Cnidium monnieri. The results were subsequently compared with tyrosinase inhibitor commonly used in skin whitening products (arbutin). Furthermore, the stability of the extract in cosmetic vehicles was assessed for the cosmetic application.

\section{Materials and Methods}

\subsection{Chemicals}

All tissue culture medium and components were purchased from GIBCO BRL (Long Island, NY USA). MTT, sodium phosphate, HCL and charcoal were from Sigma-Aldrich (St. Louis, MO, USA). Protease inhibitor cocktail was from Boehringer-Mannheim (Indianapolis, IN, USA).

Angelica koreana and Cnidium monnieri were purchased from the oriental medicine market located in Seoul, South Korea. Each of plants was sliced and weighed. $100 \mathrm{~g}$ of powder from each plant was extracted with $500 \mathrm{~mL}$ of ethanol: water (80:20, v/v) at 
room temperature for 7 days. After filtration, this extract was evaporated to dryness under vacuum, and then completely dried by lyophilization. Each extract was fractionated with different solvents(ether, hexane, chloroform, ethylacetate, butanol, and water), and was used as the sample in this study.

The sample (White-AKTM ) used in this experiment is powder form and the main component was identified coumarin as shown in [Fig. 1].<smiles>COc1ccc2ccc(=O)oc2c1CC=C(C)C</smiles>

[Fig. 1] The chemical structure of coumarin.

\subsection{Cells and culture}

B16 melanoma cells were purchased from Korean Cell line bank and cultured in DMEM (Dulbecco's modified eagle's medium, sigma, D-2902, St. Louis, MO 63178 USA) supplemented with penicillin (100 U/mL), streptomycin $(100 \mathrm{U} / \mathrm{mL})$, and $10 \%$ fetal bovine serum (Fetal bovine serum, Gibco, 26140-079, Invitrogen Co.) at $37{ }^{\circ} \mathrm{C}$ in an incubator flushed continuously with $5 \%$ $\mathrm{CO}_{2}[13]$

\subsection{Cell treatment}

B16 Melanoma cells were seeded 6-well plate at a density of 2.5x104 cells per well and allowed to attach for 24hr. After then, triplicate cultures were fed with fresh medium containg various concentrations of compound. After $48 \mathrm{hr}$, the medium was replaced with the same, fresh test medium. After further $48 \mathrm{hr}$, cells are harvested with $0.5 \mathrm{~mL}$ of $0.25 \%$ trypsin/EDTA. After dislodging the cells with occasional agitation, $2 \mathrm{~mL}$ of medium were immediately added to inactivate the trypsin, and $100 \mathrm{~mL}$ aliquot were seeded into 96-well plate for MTT assay, as described below. The remainder cell suspensions were centrifuged for $5 \mathrm{~min}$ at 2,500g, washed with PBS and then solubilized in 200 $\mathrm{mL}$ of extraction buffer (1\% Nonidet P-40, $0.01 \%$ SDS, $0.1 \mathrm{M}$ Tris- $\mathrm{HCl} \mathrm{pH} 7.2$ and protease inhibitor cocktail). Extracts were solubilized at $4 \mathrm{oC}$ for at least $1 \mathrm{hr}$ and then assays were conducted for each sample, in triplicate.

\subsection{MTT assay}

The test materials were added and incubated in 5\% $\mathrm{CO} 2$ incubator at $37^{\circ} \mathrm{C}$ for $12 \mathrm{hrs}$ by the same procedure of NR assay and $0.01 \mathrm{ml}$ of MTT at the conc, of $5 \mathrm{mg} / \mathrm{ml}$ in PBS was added into well and incubated for 4hrs, and then the residual contents were removed by turn over. To dissolve formazan crystal, isopropanol containing $0.04 \mathrm{~N} \mathrm{HCl}$ was added and stirred for $20 \mathrm{~min}$ and it was read by ELISA reader in the dual ranges of $570 \mathrm{~nm}$ and $630 \mathrm{~nm}[4]$.

\subsection{Inhibition of melanization}

B-16 melanoma cells were cultured in DMEM supplemented with $10 \%$ FBS in humidified incubator at $37{ }^{\circ} \mathrm{C}$ under $5 \% \mathrm{CO}_{2}$ in 6 well plate at density of $2 \times 104$ cells/well. After cells were attached, medium was replaced with DMEM containing 10\% FBS, $0.2 \mathrm{mM} \mathrm{a}$ -MSH, 2mM theophylline after samples addition. After 4days, trypsin was added and cells were collected by centrifugation. Then cell pellets were dried and dissolved in $1 \mathrm{~N} \mathrm{NaOH}$ Melanin synthesis inhibition rates were measured at $490 \mathrm{~nm}$ using ELISA reader[7].

\subsection{Western Blotting}

Cells were treated as described above, At the end of each treatment period, cells were washed in PBS and were lyzed in extraction buffer containing $1 \%$ Nonidet P-40, $0.01 \%$ SDS, and the protease inhibitor cocktail. Protein contents were determined with a BCA assay kit (Pierce, Rockford, IL) and equal amounts of each protein extract (10 mg per lane) were resolved using 8 
\% SDS polyarylamide gel (Koma Biotech, Korea) and transblotted onto nitrocellulose membranes (Amersham, Piscataway, NJ) and the membranes were blocked with $5 \%$ nonfat milk in TBS buffer. Following the blocking, the membranes were incubated with a PEP7 (anti-tyrosinase) a PEP1 (anti-TRP1), or a PEP8 (anti-TRP2) (each at a 1:1000 dilution). The membranes were then incubated with $\mathrm{HRP}-$ conjugated anti-rabbit IgG at a dilution of 1:2000. Immunoreactive bands were detected with enhanced chemiluminescence using an ECL kit (Amersham, Piscataway, NJ) according to the manufacture's instruction[14].

\subsection{Skin irritation test}

$5 \%$ of White- $\mathrm{AK}^{\mathrm{TM}}$ in dipropyleneglycol was formulated into control essence and cream vehicles. The final concentration of White- $\mathrm{AK}^{\mathrm{TM}}$ was $0.2 \mathrm{wt} \%$. Test materials were applied to the upper outer arm of subjects for up to $4 \mathrm{~h}$, following the specific testing format of the test developed for chemical irritation prediction. A positive control was tested in each study. Liquid test materials were applied neat, in a $0.2 \mathrm{ml}$ volume to $25 \mathrm{~mm}$ Hill Top Chambers (Hill Top Research, Inc., Cincinnati, OH). The duration of exposure to the test materials increased progressively from 30 min through $1,2,3$, and $4 \mathrm{~h}$. The sites were graded at 24,48 , and $72 \mathrm{~h}$ after patch removal using a 4 -point $\left(0-3^{+}\right)$grading scale of increasing irritation as follows[15]:

0: No reaction.

+: Weak positive reaction, mild erythema across most of the treatment site.

++: Moderate positive reaction; distinct erythema across entire treatment site, possibly spreading beyond treatment site.

+++: Strong positive reaction; spreading erythema with edema.

\subsection{Statistics}

All data were expressed as means \pm S.D. The statistical significance for the comet assay was evaluated with student's t-test and for the clinical study with one-way ANOVA. $\mathrm{P}<0.05$ was considered significant

\section{Results and Discussion}

\subsection{MTT assay}

When selecting whitening agents, one of the important points is that they should have minimal effect on melanocyte cell proliferation. Thus, the proliferation of the cells treated with White- $\mathrm{AK}^{\mathrm{TM}}$ was evaluated by MTT assay. As shown in [Fig. 2], White- $\mathrm{AK}^{\mathrm{TM}}$ showed little inhibitory effect on cell proliferation at the tested concentration. This result suggests that White- $\mathrm{AK}^{\mathrm{TM}}$ can be a safe candidate of whitening agent.

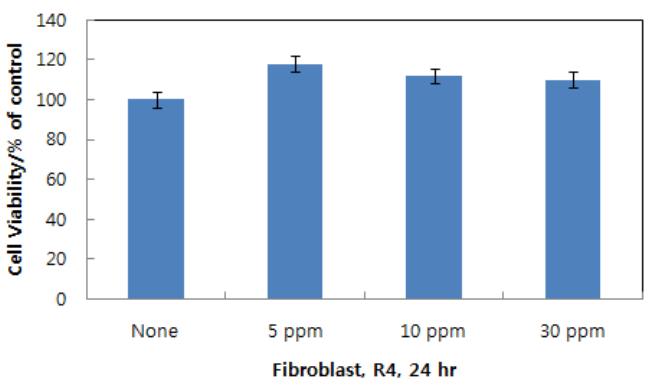

[Fig. 2] White-AK ${ }^{\mathrm{TM}}$ did not show any inhibitory effect on cell proliferation. Fibroblast cells were treated with or without White-AK ${ }^{\mathrm{TM}}$. After 4 days, cells were harvested. Values are the averages of three determinations \pm S.D.

\subsection{Skin Irritation Test}

We tested primary irritation test of White- $\mathrm{AK}^{\mathrm{TM}}$ in cosmetic vehicles. The primary skin irritation was normally the main problem of natural extract in application on the skin. We tested several concentration 
of White- $\mathrm{AK}^{\mathrm{TM}}$ When cosmetic essence and cream with White $-\mathrm{AK}^{\mathrm{TM}}$ was tropically applied, there was no detectable irritation as shown in <Table 1$\rangle$. Thus White- $\mathrm{AK}^{\mathrm{TM}}$ could be used as an anti-irritation agent.

〈Table 1〉 Primary skin irritation score of White-AK ${ }^{\mathrm{TM}}$.

\begin{tabular}{|c|c|c|c|}
\hline \multicolumn{2}{|c|}{ Vehicles } & Concentration of & Irritation Score \\
\hline Essence & Type A & - & $0.16 \pm 0.01$ \\
\hline Essence & Type A & 0.1 wt $\%$ & $0 \pm 0.01$ \\
\hline Essence & Type A & 0.3 wt $\%$ & $0 \pm 0.01$ \\
\hline Essence & Type B & - & $0.02 \pm 0.01$ \\
\hline Essence & Type B & 0.2 wt $\%$ & $0.01 \pm 0.01$ \\
\hline Cream & Type & - & $0.01 \pm 0.01$ \\
\hline Cream & Type & $0.2 \quad$ wt $\%$ & $0 \pm 0.01$ \\
\hline
\end{tabular}

\subsection{Effect of White-AKTM on pigmentation} of B16 melanoma cell

The quantization of the melanin was analyzed through ELISA to examine the White $-\mathrm{AK}^{\mathrm{TM}}$ for inhibitory activity against melanin synthesis. The result is given [Fig. 3]. The White $-\mathrm{AK}^{\mathrm{TM}}$ show excellent whitening effects on the B16 melanoma cells. The calculated value of $\mathrm{EC}_{50}$ was $2.7 \mathrm{ppm}$.

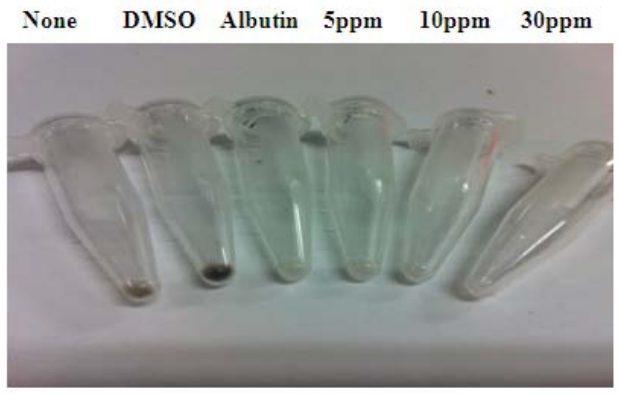

[Fig. 3] The melanin precipitates of B-16 melanoma

\subsection{Effect of White-AK ${ }^{\mathrm{TM}}$ on expression of tyrosinase}

To explore the mechanism responsible for the decreased pigmentation, we examined changes in the proteins levels of three important melanogenic enzymes (tyrosinase, TRP-1, $\beta$-actin) using western blotting. The results were shown in Figure 4 . When compared with untreated control, 5 and 10ppm White- $\mathrm{AK}^{\mathrm{TM}}$ inhibited protein expression dramatically without any effect on TRP-1and $\beta$-actin. These results suggest that whitening potency of White- $\mathrm{AK}^{\mathrm{TM}}$ results mainly from down regulation of expression of tyrosinase .

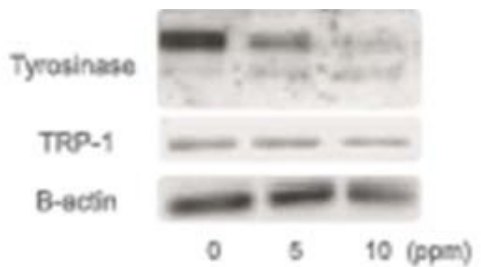

[Fig. 4] Western blotting Image of specific detection of tyrosinase, TRP-1, $\beta$-actin.

\subsection{Stability of White- $A K^{T M}$}

[Fig. 5] and [Fig. 6] demonstrated the stability of $5 \%$ of White- $\mathrm{AK}^{\mathrm{TM}}$ dipropyleneglycol solution in transparent and opaque bottle during 1 month storage at under outdoor ultraviolet (UV) condition or indoor at $50^{\circ} \mathrm{C}$.

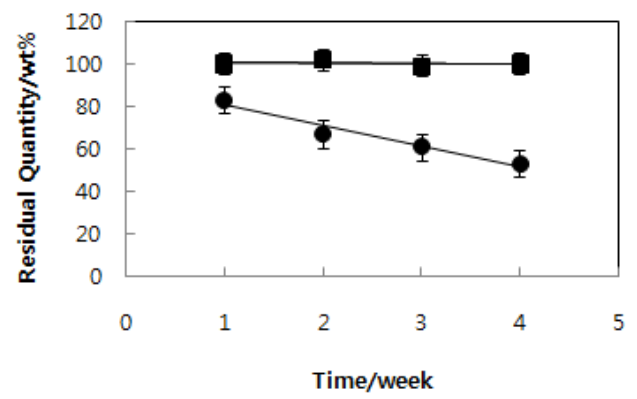

[Fig. 5] Recovery percent of $5 \%$ of White-AK ${ }^{T M}$ in DPG solution under outdoor ultraviolet(UV) condition: $\bullet$; in transparent bottle, $\mathbf{a}$ in opaque bottle.

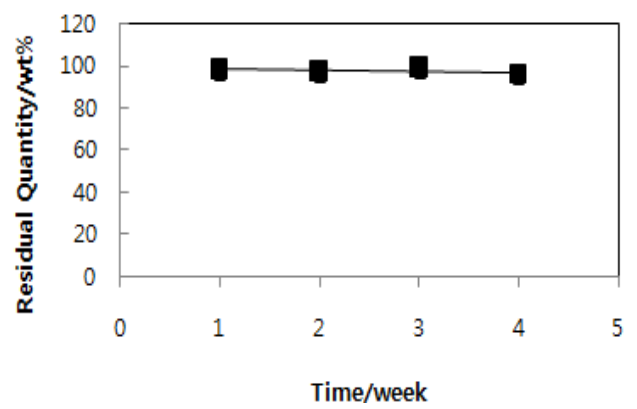

[Fig. 6] Recovery percent of $5 \%$ of White- $A K^{\mathrm{TM}}$ in DPG solution at $500 \mathrm{C}$. 


\section{Conclusions}

The results of this study clearly demonstrated that the extract of Angelica koreana, Cnidium monnieri, was able to reduce melanin formation in $\mathrm{B}-16$ melanoma cell. The major component of extract was coumarin. Comparing to arbutin commonly used in whitening products like kojic acid and licolice extract, White- $\mathrm{AK}^{\mathrm{TM}}$ showed quite effective efficacy on skin whitening. The mechanism of whitening effect is thought to be down regulation of expression of tyrosinase. From the primary skin irritation test, the extract appears to have a very promising potential for use as a safe, effective and economical whitening agent in the cosmetic industry. More studies were carried out to determine the optimal concentration, stability as well as safety and efficacy of White- $\mathrm{AK}^{\mathrm{TM}}$.

\section{ACKNOWLEDGMENTS}

This work was financially supported by the global cosmetic projects of Ministry of Health \& Welfare, Republic of Korea (Project No. A103017-1213-1570200).

\section{REFERENCES}

[1] S. Kirstein, A. Denecke, S. Hasler, H. Wersing, H. Gross, and E. Korner, A vision architecture for unconstrained and incremental learning of multiple categories, Memetic Computing, Vol. 1, No. 4, pp. 291-304, 2009.

[2] A. Tonda, E. Lutton, and G. Squillero, A benchmark for cooperative coevolution, Memetic Computing, Vol. 4, No. 4, pp. 263-277, 2012.

[3] N. Smit, J. Vicanova, and S. Pavel, The Hunt for Natural Skin Whitening Agents, Int. J. Mol. Sci., Vol. 10, pp. 5326-5349, 2009.

[4] K. K. Lee, and J. D. Choi, The effect of Areca catechu L. extract on anti-inflammatory and antimelanogenesis, Int. J. Cosmet. Sci., Vol. 21, pp. 275-284, 1999.

[5] K. Shimizu, R. Kondo, K. Sakai, and H. Sato, The inhibitory components from Artocarpus incises on melanin biosysnthesis, Planta Med., Vol. 64, No. 5, pp. 408-412, 1998.

[6] D. I. Jang, B. G. Lee, C. O. Jeon, N. S. Jo, J. H. Park, S. Y. Cho, H. Lee, and J. S. Koh, Melanogenesis inhibitor from paper mulberry, Cosmetic and Toiletries, Vol. 112, pp. 59-62, 1997.

[7] T. Yokota, H. Nishio, and Y. Kubota, The inhibitory effect of glabridin from licolice extracts on melanogenesis and inflammation, Pigment Cell Res., Vol. 11, pp. 335-361, 1998.

[8] H. Matsuda, S. Nakamura, and M. Kobo, Studied of cuticle drugs from natural sources. II. Inhibitory effects of prunus plants on melanin biosynthesis, Biol. Pharm. Bull., Vol. 17, pp. 1417-1420, 1994.

[9] S. Kiefer, M. Weibel, J. Smits, M. Juch, J. Tiedtke, and N. Herbst, Citrus Flavonoids with Skin Lightening Effects, Safety and Efficacy Studies, SOFW J.,| Vol. 136, No. 12, pp. 45-54, 2010.

[10] J. H. Kim and K. T. Lee, Inhibitory effects of Morus alba extracts on melanogenesis, Cosmetic and Toiletries, Vol. 113, pp. 65-76, 1998.

[11] S. Leong, Who's the Fairest of Them All? Television Ads. for Skin-whitening Cosmetics in Hong Kong, Asian Ethnicity, Vol. 7, No. 2, pp. 167-181, 2006.

[12] B. Sritularak, W. De-Eknamkul, and K. Likhitwitayawuid, Tyrosinase inhibitors from Artocarpus lakoocha, Thai J. Pharm. Sci., Vol. 22, pp. 149-155, 1998.

[13] K. Yoshiura, T. Nishishita, T. Nakaoka, N. Yamashita, and N.i Yamashita, Inhibition of B16 melanoma growth and metastasis in C57BL mice by vaccination with a syngeneic endothelial cell line, J. Exp. \& Clin. Can. Res., Vol. 28, No. 13, pp. $1-6,2009$.

[14] H. Chassaigne, V. Tregoat, J. V. Norgaard, S. J. Maleki, and A. J. van Hengel, Resolution and 
identification of major peanut allergens using a combination of fluorescence two-dimensional differential gel electrophoresis, Western blotting and Q-TOF mass spectrometry, J. Proteomics, Vol. 72, No. 3, pp. 511-526, 2009.

[15] D. Basketter, D. Jirova, and H. Kandarova, Review of skin irritation/corrosion Hazards on the basis of human data: A regulatory perspective, Interdiscip. Toxicol., Vol. 5, No. 2, pp. 98-104, 2012.

\section{조 완 구(Cho, Wan Goo)}

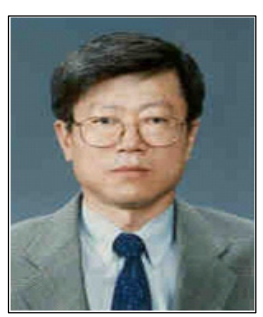

- 1980년 2월 : 서울대학교 화학교육 과(이학사)

-1997년 10월 : University of Hull(이 학박사)

· 1980년 1월-1984년 3월: 아모레퍼시 픽, 선임연구원

· 1984년 4월-2006년 3월: LG 생건, 선임, 책임연구원, 연구소장(상무)

- 2006년 9월 현재 : 전주대학교 기초의과학과 교수

- 관심분야 : 화장품, 에멀젼

•E-Mail : wgcho@jj.ac.kr

\section{김 청 택(Kim, Cheong Tack)}

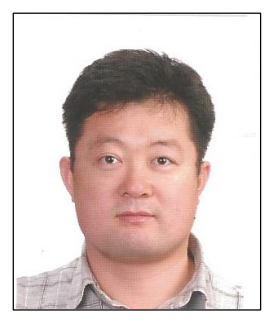

- 1994년 2월 : 서울대학교 약학과(약 학사)

- 1996년 2월 : 서울대학교 약학과(약 학석사)

- 1996년 1월-2008년 12월: LG 생건 선임, 책임연구원

- 2009년 6월 현재 : 주) 알앤애스 대표

- 관심분야 : 화장품 원료, 피부 미백제

·E-Mail : happilion@biorns.com 